\title{
ДОСЛІДЖЕННЯ ВПЛИВУ ЦИКЛІЧНИХ ПРОЦЕДУР НА ВИРІШЕННЯ ЗАДАЧІ ПІДВИЩЕННЯ ЕФЕКТИВНОСТІ ФУНКЦІОНУВАННЯ ПРОГРАМНОГО ЗАБЕЗПЕЧЕННЯ СИСТЕМ РЕАЛЬНОГО ЧАСУ
}

\section{Вступ}

Широке впровадження програмного забезпечення (ПЗ) систем реального часу зробило актуальним дослідження методів забезпечення задовільного рівня якісних показників ПЗ. Так для ПЗ систем реального часу існуе загальна система показників якості [1]. До складу такої системи входять наступні характеристики: точність вхідних даних, діапазони зміни параметрів, час реакції, адаптивність до зовнішніх впливів, надійність функціонування, раціональне використання ресурсів ЕОМ, часові показники, мобільність та інші. Для забезпечення необхідного рівня якості показників ПЗ може бути запропоновано два різних підходи [2].

- Вирішення оптимізаційної задачі з одним критерієм. В цьому випадку замовник ПЗ робить вибір одного з показників якості. Задача максимально підвищити рівень якості даного показника.

- Вирішення багатокритеріальної задачі. В цьому випадку замовник обирає одразу декілька показників якості ПЗ, та встановлюе вагові коефіціенти кожного з показників. Задача максимально підвищити рівень обраних показників з урахуванням коефіцієнтів важливості.

\section{Постановка задачі}

Замовник в технічному завданні визначає задані значення показників якості ПЗ. 3 іншого боку, є створена для конкретної предметної області база рекомендацій, щодо поліпшення різних показників якості. Зрозуміло, що використання рекомендації впливає одразу на значення декількох показників якості. Цей вплив для одних показників може бути позитивним, а для інших від'ємним. Тому задача вибору рекомендацій $є$ оптимізаційна, та їі вирішення потребує наступних досліджень:

1. Дослідження методів розрахунку показників якості програмних модулів систем реального часу.

2. Дослідження впливу циклічних процедур на розрахунок показників якості програмних модулів.

3. Дослідження корекції заданих показників якості вузлової програмної компоненти (ПК).

(c) Є.В. Крилов, В.К. Анікін, 2010 
4. Дослідження способів добору рекомендацій щодо підвищення ефективності функціонування ПЗ систем реального часу.

Результати дослідження методів розрахунку показників якості програмних модулів були викладені у статті [3]. Ця стаття присвячена дослідженню впливу циклічних процедур на розрахунок показників якості програмних модулів та корекції заданих показників якості вузлової $\Pi \kappa$.

\section{Вирішення задачі визначення коефіцієнтів структури для вузлів з циклічними процедурами}

В статті [3] було досліджено формулу, яка дозволяе розрахувати коефіціенти структур без урахування циклічних процедур $K_{s_{j}}$, присутність яких в алгоритмі функціонування вузла вносить додаткові корективи у процедуру визначення заданих показників якості ПК вузла. Дійсно ПК, що знаходиться усередині ітераційного циклу, при передачі керування вузлу може виконуватись кілька разів, і тим самим збільшувати оцінку можливості свого виконання по відношенню до тих ПК, які не охоплені циклами. Більш того, ПК може бути охоплена двома та більшою кількістю циклів.

Урахування присутності в алгоритмі фрункціонування вузла циклічних процедур в значній мірі ускладнює використання змінних значень у якості параметрів ітераційних циклів та циклів з виходом по виконанню умови. В цьому разі параметри циклів визначаються експертним шляхом, що в значній мірі знижуе точність розрахунку.

Розрахунок коефіціентів структури з урахуванням циклічних процедур $\bar{K}_{s}^{c}$ виконуеться за наступною формулою.

$$
K_{s_{j}}^{c}=K_{j}^{c} \cdot K_{s_{j}},
$$

де $K_{j}^{c}$ - поправочний коефіціент на приналежність $j$-ї ПК множині циклічних процедур вузла;

$K_{s_{j}}$ - коефіціент структури $j$-ї ПК вузла без урахування циклічних процедур.

Для визначення значень вектора $\overline{K^{c}}$ необхідно скласти матрицю приналежності ПК циклічним процедурам $(C)$, елементи якої приймають такі значення.

$C_{j, r}=\left\{\begin{array}{l}k_{r} \text { (кількість повторів r-го цикла), якщо ј-а ПК охоплена r-м циклом } \\ 1, \text { в іншому випадку }\end{array}\right.$,

де $r$ - номер циклу вузла $(r=\overline{1, p} r=\overline{1 . p} ; p-$ кількість циклів у вузлі ); $j$ - номер ПК вузла $(j=\overline{1, k})$;

$K_{r}$ - кількість повторів, які передбачені в $r$-му циклі вузла.

Ненормований коефіцієнт поправки приналежності $j$-ї ПК вузла циклічним процедурам можна визначити за формулою 


$$
K_{j}^{\prime c}=\prod_{k=1}^{p} C_{j, r}
$$

Для отримання формули розрахунку поправочних коефіцієнтів $\bar{K}^{\prime c}$ пронормуємо значення вектора $\overline{K^{c}}$ таким чином, щоб виконувалась рівність

$$
\sum_{j=1}^{k} K_{j}^{c}=k
$$

В результаті отримуємо

$$
K_{j}^{c}=\frac{k K_{j}^{\prime c}}{\sum_{j=1}^{k} K_{j}^{\prime c}}=\frac{k \prod_{r=1}^{p} C_{j, r}}{\sum_{j=1}^{k} \prod_{r=1}^{p} C_{j, r}}
$$

Розв’язуючи спільно (1) та (3) одержимо остаточну формулу для розрахунку коефіцієнтів структури вузла з циклами.

$$
K_{s_{j}}^{c}=\frac{k \prod_{r=1}^{p} C_{j, r}}{\sum_{j=1}^{k} \prod_{r=1}^{p} C_{j, r}} \cdot K_{s_{j}}
$$

Якщо підставити значення $K_{s_{j}}$,яке було визначено в статті [3] в (4), то отримуемо другу форму запису виразу (4).

$$
K_{s_{j}}^{c}=k^{2} \frac{\prod_{r=1}^{p} C_{j, r} \cdot \sum_{r=1}^{l} S_{j, r} \cdot \frac{1}{2 B_{r}}}{\sum_{j=1}^{k}\left(\prod_{r=1}^{p} C_{j, r}+\sum_{r=1}^{l} S_{r, j} \cdot \frac{1}{2 B_{r}}\right)},
$$

де $K_{s_{j}}^{c}$ - значення коефіцієнта структури з урахуванням циклічних процедур $j$ - ї ПК вузла;

$k$ - кількість ПК у вузлі;

$p$ - кількість циклів у вузлі;

$C_{j, r}$ - елемент матриці приналежності $j$ - ї ПК охопленої $r$ - м циклом;

$l$ - кількість гілок структурної схеми вузла;

$S_{j, r}$ - елемент матриці структури вузла $j$-ї ПК вузла $r$-ї гілки структурної схеми вузла;

$B_{r}$ - кількість умов в $r$-й гілці структурної схеми вузла.

Необхідно відзначити, що формула (5) дає точне рішення лише для детермінованих алгоритмів, в яких наперед відомо (є можливість досить точно оцінити) значення параметрів циклічних процедур. 


\section{Вирішення задачі корекції заданих показників якості вузлової ПК}

Подана задача вирішуеться на стадії синтезу. В результаті програмування ПК вузла може виникнути така ситуація, коли не всі ПК досягли заданого рівня якості. В цьому вкладку необхідно скорегувати значення показників якості ПК вузла. Покажемо необхідність вирішення такої задачі на наступному прикладі.

Нехай в процесі програмування неповністю виконані вимоги щодо стійкості та достовірності деяких ПК вузла, а такі показники якості як ефективність часова та демонстративність усіх ПК вузла мають значення не нижче заданих. В цьому разі, щоб досягти заданого рівня якості при програмуванні вузлової ПК необхідно сконцентрувати увагу на перших двох показниках якості (тобто, збільшити їх задані значення). 3 другого боку, для того, щоб не порушити баланс, який був встановлений на стадії проектування, необхідно знизити задані значення двох останніх показників.

3 вище викладеного зрозуміло, що для вирішення поставленої задачі необхідно ввести набір коефіцієнтів перерахунку $(\bar{k})$, значення яких характеризують необхідні ступені зниження $\left(k_{i}<1\right)$ чи підвищення $\left(k_{i}>1\right)$ значень показників якості вузлової ПК. Для того щоб не порушувати баланс, який був встановлений на стадії проектування, необхідно нормувати коефіціенти перерахунку таким чином, щоб вони задовольняли наступному виразу:

$$
\sum_{i=1}^{m} k_{i}=m
$$

де $m$ - кількість показників якості.

Таким чином, загальна формула корекції заданих значень показників якості вузлової ПК може бути виражена наступним відношенням

$$
P_{3}^{B}=k_{i} \cdot P_{3_{i}}^{\prime B},
$$

де $P_{3_{i}}^{B}$ - скоректоване значення $i$-го показника якості вузлової ПК;

$k_{i}$ - коефріцієнт перерахунку $i$-го показника якості;

$P_{{ }_{3}}^{\prime B}$ - задане значення $i$-го показника якості вузлової ПК, яке визначене на стадії проектування.

Визначимо значення $k_{i}(i=\overline{1, m})$.

Коеріцієнт перерахунку $i$-го показника якості $\left(k_{i}\right)$ повинен бути пропорційним сумарному значенню відхилень поданого показника від заданих величин усіх ПК вузла.

$$
k_{i}=l \sum_{j=1}^{k} E_{i, j},
$$

де $l$ - коефіціент пропорційності, що виконує вимоги нормованості значень коефріцієнтів перерахунку; 
$E_{i, j}$ - відхилення $i$-го показника якості від заданого вчення в $j$-й ПК вузла.

Після спільного вирішення (8) та (6) отримаемо формулу розрахунку коефіцієнта пропорційності $l$.

$$
l \sum_{i=1}^{m} \sum_{j=1}^{k} E_{i, j}=m
$$

3 урахуванням (9) одержимо вираз для коефріцієнта пропорційності $l$.

$$
l=\frac{m}{\sum_{i=1}^{m} \sum_{j=1}^{k} E_{i, j}}
$$

Якщо підставити (10) в (8), то отримаємо формулу для розрахунку коефіціента перерахунку $i$-го показника якості $\left(k_{i}\right)$.

$$
k_{i}=\frac{m \cdot \sum_{j=1}^{k} E_{i, j}}{\sum_{i=1}^{m} \sum_{j=1}^{k} E_{i, j}},
$$

де $m$ - кількість показників якості; $k$ - кількість ПК у вузлі; $E_{i, j}$ - відхилення рівня $i$-го показника якості від заданої при програмуванні $j$-ї ПК вузла.

\section{Висновок}

Присутність циклічних процедур в алгоритмах управління систем реального часу вносить додаткові корективи у процедуру визначення показників якості вузла. Для коригування цього впливу необхідно ввести поправочний коефіцієнт на приналежність ПК множині циклічних процедур вузла, який розраховуеться за формулою (5).

Задачу корекції заданих показників якості вузлової програмної компоненти (ПК) необхідно вирішувати на стадії синтезу. Коефіцієнт перерахунку для кожного вузла обчислюеться за формулою (11).

\section{Література}

1. Липаев В.В. Проектирование программного обеспечения. М.:Финансы и статистика.

2. Бутаков Е.В. Методы создания качественного программного обеспечения.

3. Крилов С.В., Анікін В.К. Методи та засоби підвищення ефрективності функціонування програмного забезпечення систем реального часу. Адаптивні системи автоматичного управління - Дніпропетровськ: Системні технології, 2007. Вип.10. 